generation demonstrated by the Marchi method; (3) absence in increase of weight (important in distinguishing grossly from edema); (4) absence of exudative changes.

Epileptics are somewhat prone to exitus with soft brain. The condition seems to be associated with a terminal exhaustion. The illustrative case was that of an epileptic, dying at forty-two, was of importance in that it showed the same histological changes in the midst of a sclerotic area, as were shown by the remainder of the brain and cord. Thus the lysis, while it appears to be a general histolysis, is actually a differential cytolysis or axonolysis. Enlargements were shown from photomicrographs of axonal reactions in various types of cell from the illustrative case.

\title{
DEMENTIA PRAECOX.
}

By Dr. Brownrigg.

Indications of beginning mental enfeeblement may be explained as wholly dependent upon other bodily illnesses or irregularities and incipent dementia præcox may be overlooked by general practitioners for weeks or months before a threatened insanity is suggested. Many such cases are recognized as nervous and put down under the general term, "neurasthenia" when close observation by experienced men cannot fail to detect even quite early the probable essential trouble. Thus slight attacks of dementia præcox may be recovered from at home without special treatment, and only subsequently when an attack brings commitment to insane hospital does the previous mild history disclose a former, but sufficiently, well marked attack that ought to have been recognized as such and more caution followed. These patients then follow the course of those that have more violent attacks from the beginning and by degrees going downward generally offer as poor a prognosis as those committed to asylums at first.

From analysis of New Hampshire State Hospital records of the last three years, 33 per cent. of dementia pracox patients "recovered" or were very much improved so as to undertake their former work. Six per cent. became perfectly normal as far as could be determined. Fifty-three per cent. had not improved, or showed only sight improvement. But of those that did not improve nuch, the duration of the illness previous to hospital treatment was about two years, and of those that "recovered" or "much improved" the duration before commitment was only two months.

From the past five years experience with psychasthenic cases that could be classed as probably undoubted cases of incipient dementia præcox the conclusion is drawn that such early cases under early treatment in private hospitals where they could have careful control and individual attention and separation from other more definitely insane cases, offered a much more favorable prognosis as to both early and more complete recovery than similar ones, that by habit and progress of the disease, had become more damaged mentally. In fact dementia præcox has probably in a large proportion of cases a more or less prolonged prodromal period with "neurasthenic" symptoms predominating, and in this period the disease is not at all the hopeless affection that it becomes later when complete loss of control has developed.

In treatment emphasis was laid on isolating the patient from friends and customary surroundings and most of all on the need of judicious moral treatment and control. To this end much personal time of the physician and especially trained nurses are essential.

Dr. Folsom said Dr. Brownrigg's experience was somewhat in the same line as his own. Looking up post-typhoid psychoses he found that the prognosis of cases treated in the insane hospitals was reported as more unfavorable than for cases treated outside the hospitals for the insane, and he thought the same is probably true of dementia prrcox. The explana:tion is in part that the worst cases go to the hospital, but the hospital influences, with its surroundings and associations, are bad for quite young 
people. The outlook is better for such patients out of the hospital. Dr. Folsom's impression is that dementia præcox is not uncommon; at least the cases like dementia pracox that go on to complete dementia are not unusual. The diagnosis is often overlooked, as Dr. Brownrigg says, as is especially true of mild cases in early stages. Some cases of dementia pracox resemble chorea so far as the mental condition is concerned; that is, the limitation of intellectual capacity is the most prominent symptom. Now and then in girls of 18 or 20 we find cases with very slight choreic movements, but with marked impairment of intellectual power which possibly might be called either chorea or dementia præcox. In the case of a girl, for instance, who was taking fencing lessons the fencing master was the first to find that she could not co-ordinate the movements of her right wrist. The subject of diagnosis is often open to doubt or dispute in individual cases and requires a good deal of careful thought.

Dr. McDonald said that since Jan. I, I903, there have been discharged from Butler Hospital 389 patients. Of these, 74 ( 19 per cent.) were diagnosed as cases of dementia præcox. In the hospital at the present time are 75 cases of dementia pracox, so that we have 149 cases of dementia præcox in which to consider the prognosis. This number does not include doubtful cascs, but only thosc in which the diagnosis was made with a reasonable degree of certainty. Fifty-seven wcre males, 92 females; $;$. $e_{\text {., }}$ 6I.7 per cent. were womcn. These figures disagree somcwhat with those of Prof. Kraepelin, who says that the disease is approximately equally divided in the two sexes. Of these cases, 6.6 per cent. have died; 33.5 per cent. proceeded to a very deep and apparently abiding state of dementia; $i$. $e$, deep apathy with neither depression or exhileration, combined with various symptoms which have been characterized as diagnostic of dementi præcox; $i$. e.. negativism, catatonia. impulsive and foolish behavior, mannerisms, verbigeration, etc. 38.2 per cent., while not advancing to this deep dementia, remained unimprored: that is. with more or less acute symptons, such as hallucinations, delusions, foolish bchavior, etc., with more or less of the characteristics of mental defect. Four per cent. improved slightly, but not sufficicntly to permit a return to the home. 16.7 per cent. made a partial recovery; that is, improved to such an extent that they were able to live at home without particular friction, or would be able to live at home if the home conditions were not extremely unfavorable. Many of these have taken up their old life to a considerable extent. Some are capable of occupation and a number are earning their own living. This 16.7 per ccnt. corresponds to those cases, which Kraepelin considers as recovered, though not necessarily without perceptible defect. 6 per cent.; mamely, one case (female) has apparently recovered entirely so that not only the friends, but also physicians are unable to detect evidence of even a minor degree of mental deterioration. We see, therefore, that the prognosis of dementia pracox is extremely bad. The class of cases giving the best prognosis and from which the largest number of recoveries were drawn, are the catatonics. We are warned, however, from this circumstance to regard with suspicion our diagnosis of dementia pracox where catatonia is present to a marked degree in the acute stages, particularly where there is a condition of catatonic stupor. In these cases we have made many incorrcct diagnoses in the past, and expect to make still more in the future. A number of patients where this diagnosis has been made, proved eventually to be probable cases of melancholia-mania, and we are of the opinion that catatonic stupor is not diagnostic of dementia pracox, though the condition, of course, occurs in that disorder as well as in other mental disturbances.

Dr. F. H. Packard said that the diagnosis of dementia precox is apt to be difficult in many stages of the disease, and it is often especially so in those very early stages of which Dr. Brownrigg has spoken. He thought one should remember that there is, so to speak, often what might be called a normal abnormality during the period of adolescence which fades away 
and does not lead to a dementia pracox. While it is usually or often at this period that dementia pracox begins, one should bear in mind these normally abnormal conditions, and be guarded about calling them recoveries from dementia præcox. What he wished to speak about more particularly are those cases in a more advanced condition as usually seen in the hospitals. From his experience with such cases he was rather sceptical when he heard people talking of recoveries from dementia præcox, and he suspected that in many such cases thcre was either a wrong diagnosis made or that the patients were not followed carefully enough or long enought As to nlaking a wrong diagnosis, he was quite sure this is often done, especially in those cases of stupor where the prcvious history is not well known and where the cases are not carefully analyzed. For a considerable time catalepsy has been considered by many as almost a pathonomonic sign of dementia pracox, yet he had seen this phonomenon in cases where the previous history showcd that the way into the stupor and cataleptic condition was typical of a manic-depressive condition, and where the course and ontcome of the case showed that without doubt it was a case of manic-depressive insanity. What he wished to emphasize is the necessity of considering more than the picture of the momcnt, as for example, when one secs a cataleptic condition one must not say inmediately that this is a dementia precox. As to the second point, he was likewise quite certain that many of the so-called recoveries are not followed carefully enough or long enough. Within a comparatively recent time several cases have been obscrved at the McLean Hospital with such definite symptoms of dementia precox that there was no hesitation in making such a diagnosis and giving a bad prognosis. Nevertheless, these patients recovcred sufficicntly to go home and be pronounced cured by their relatives. He might say that it was almost with pleasure that within the last two months he saw two such cases returncd to the hospital, again showing unmistakable symptoms of dementia precox. One has progressed so rapidly that there is no longer any question of recovery. The other one likewisc is in a very doubtiul condition. Careful qucstioning showed that ever since lcaving the hospital one of these patients, called well, was scarccly able to do more than simple thing's like feeding the chickens. He would emphasize the necessity of more careful diagnosis and of nore careful and longer obscrvation before speaking definitcly about rccoveries from dementia pracox.

Dr. Mitchell said that the paper opcned to discussion a very difficult problem. The accurate differentiation of dementia precox from other psychoses was often unccrtain. long after the patient had shown symptoms necessitating hospital care, and this uncertainty must be evcn greater in the diagnosis of early cascs. He thought critical care shot1ld be exercised in making the diagnosis of dementia precox on ncurasticnic or psychasthenic symptoms. becat1se in taking histories of hospital cases, diagnosed as manic-deprcssive insanity, it was frequently found that the first attack was regarded as neurastlenia or "nervous prostration," and that this condition would bc followed later by a well marked manic-depressive state. It is also difficult to determine that a patient suffering from dementia pracox has recovered, and this estimate could not be considered well founded unless the patient displayed normal conduct and unimpaired intellect for a long period. Hospital experience demonstrates that many patients who show temporary improvement following the first outbreaks of this disease, and who might at this period bc considered as recovered, eventually show progress of symptoms that cither incapacitates them for leading useful lives or again requires hospital restraint.

Dr. H. W. Miller agreed with what has been said relative to the difficulty of diagnosticating in the carly stages of dementia præcox. It is by no means easy, and we are often lcd astray. This uncertainty often causes one to question the diagnosis of dementia pracox when the patient makes a good recovery. That some cases do recover seems unquestionable. We 
have little expericnce with very early cases in a public institution such a Taunton Hospital is, and our recovery rate in this class is unfortunately low; the majority of the recoveries belong to those cases ushered in with acute symptoms, chiefly the katatonic type. He felt that the tendency is to use the term dementia pracox too loosely, and that we are inclined to group in this class eases which do not properly belong there because the symptoms are ill-defined, and do not seem to fit satisfactorily into any other group. He was interested in the discussion on this subject at the British Medical Association mecting in Toronto, where criticism of the name dementia pracox was quitc gencral among the British psychiatrists.

Dr. Folsom did not mean that cases should not have proper and individual treatment. If people have resources and suitable means for treatment, young patients are, as a rule, better cared for outside of a hospital for the insane, because they are at a very receptive age, and the suggestions from hospital life are demoralizing to them. But if a hospital is necessary, a smatl one like that at Nashua is preferable to a large one. Proper treatment for the individual case is a necessity for the best results, and for that the insane hospital may be the only available means, even if objectionable, in some ways, except for the worst cases.

Dr. Knapp said that Dr. Folsom had rather anticipated what he was about to say. Dr. Brownrigg's cases illustrate the importance of early treatment, which is of great importance. He thought that there are a good many cases of sensory phrenosis that get entirely well and remain permanently well if they receive propcr treatment early in the attack. In many cases, however, asylum treatment is not the best thing in the way of treatment, but proper trcatment outside is usually a very expensive matter, so expcnsive as to be beyond the means of many, and the prejudice against asylums and the legal restraints that bar free admission often result in fatal delay. He was glad to hear from Dr. Miller that our English brethren have not succumbed to the perversions of the mother tongue and object to the term "dementia pracox." He had used Bianchi's term, "sensory phrenosis," in preference. On Kraepelin's own showing, "dementia præcox" is often neither "dementia" nor "pracox."

Dr. Folsom said as regards the expense of which Dr. Knapp speaks he did not think it need be great, if onc is ready to run considerable risk as to suicide, as he often did, for the better chance of recovery.

Dr. Brownrigg was in agreement for advanced cases of dementia pracox, with those who are pessimistic about a possible complete recovery, but he believed that in the early stages wherc no dementia is present the affection seems essentially to be a curable one. Dementia symptons come later, and appcar secondary to the progress of some underlying changes, but before these have progressed far, treatment seems more effectual and the prognosis not at all bad. 